\title{
Comparison of early clinical results and re-tear rates of transosseous-equivalent rotator cuff repairs with or without medial knots
}

\author{
Medial düğümlü veya düğümsüz transosseöz eşdeğeri rotator manşet onarımlarının \\ erken klinik sonuçları ve tekrar yırtık oranlarının karşılaştııılması
}

\author{
Tahsin Gürpınar, $\mathrm{MD}^{1}{ }^{\mathbb{D}}$, Barış Polat, $\mathrm{MD}^{2} \mathbb{D}$, Saltuk Buğra Tekin, $\mathrm{MD}^{1} \mathbb{1}$, Ayşe Esin Polat, $\mathrm{MD}^{3} \mathbb{D}$, \\ Engin Çarkçı, MD ${ }^{1} \mathbb{D}$, Yusuf Öztürkmen, $\mathrm{MD}^{1}{ }^{1}$
}

\begin{abstract}
'Department of Orthopedics and Traumatology, İstanbul Training and Research Hospital, İstanbul, Turkey ${ }^{2}$ Department of Orthopaedics and Traumatology, University of Kyrenia, Faculty of Medicine, Kyrenia, Cyprus ${ }^{3}$ Department of Orthopaedics and Traumatology, Dr. Akçiçek State Hospital, Kyrenia, Cyprus
\end{abstract}

\begin{abstract}
Objectives: This study aims to compare the clinical results and repair integrity of two of the commonly used transosseousequivalent arthroscopic rotator cuff repair techniques, which are the knotless and the medial knotted suture bridge, for patients with full-thickness medium to large-sized rotator cuff tears.

Patients and methods: The study included 121 patients (55 males, 66 females; mean age $56.7 \pm 7.3$ years; range, 39 to 72 years) with cuff tears. In total, 64 shoulders were operated on using the conventional medial knotted suture bridge technique (group A) and 57 shoulders were operated on using the knotless suture bridge technique (group B). The Constant score, visual analog scale (VAS) and active forward flexion angle were assessed preoperatively and after a minimum of 12 months postoperatively. Postoperative rotator cuff integrity was evaluated by magnetic resonance imaging (MRI) after a mean of $19 \pm 4.7$ months.
\end{abstract}

Results: There were no significant differences between the groups in terms of age, gender, body mass index, and anteroposterior extension of the tear on the sagittal MRIs. Postoperatively, the mean Constant score increased from $32.3 \pm 8.5$ points to $84 \pm 11.6$ points in group $\mathrm{A}$ and from $31.3 \pm 9.3$ points to $86.4 \pm 8.7$ points in group B $(p<0.001)$, while the mean VAS score decreased from $6.0 \pm 1.0$ to $1.3 \pm 1.2$ in group $A$ and from $6.4 \pm 1.0$ to $1.0 \pm 0.8$ in group $\mathrm{B}(\mathrm{p}<0.001)$. According to the control MRIs, the re-tear rate was $10.9 \%(n=7)$ in group A and $8.8 \%(n=5)$ in group B. No statistically significant difference was found in either the clinical scores or re-tear rates between the groups ( $>00.05$ ).

Conclusion: In comparison to the medial knotted technique, less time-consuming and simpler knotless technique provides similar satisfactory outcomes after a minimum of one year postoperatively. Keywords: Double-row, knotless suture bridge, medial knotted suture bridge, rotator cuff repair, transosseous-equivalent repair.
Öz

Amaç: Bu çalışmada, tam kat orta ile büyük boyutlu rotator manşet yırtığı olan hastalar için yaygın olarak kullanılan iki transosseöz eşdeğeri artroskopik rotator manşet onarımı tekniği olan düğümsüz ve medial düğümlü dikiş köprüsünün klinik sonuçları ve onarım bütünlüğü karşılaştırıldı.

Hastalar ve yöntemler: Çalışmaya manşet yırtı̆̆ı olan 121 hasta (55 erkek, 66 kadın; ort. yaş $56.7 \pm 7.3$ yıl; dağılım, 39-72 y1l) dahil edildi. Toplamda 64 omuz konvansiyonel medial düğümlü dikiş köprüsü tekniği (grup A) ve 57 omuz düğümsüz dikiş köprüsü tekniği (grup B) kullanılarak ameliyat edildi. Constant skoru, görsel analog ölçeği (GAÖ) ve aktif öne fleksiyon açısı ameliyat öncesinde ve ameliyattan minimum 12 ay sonra değerlendirildi. Ameliyat sonrası rotator manşet bütünlüğü ortalama $19 \pm 4.7$ ay sonra manyetik rezonans görüntüleme (MRG) ile değerlendirildi.

Bulgular: Yaş, cinsiyet, vücut kitle indeksi değeri ve sagital MRG'de yırtığın ön-arka genişliği bakımından gruplar arasında anlamlı farklılık gözlenmedi. Ameliyat sonrası ortalama Constant skoru grup A'da $32.3 \pm 8.5$ puandan $84 \pm 11.6$ puana ve grup B'de $31.3 \pm 9.3$ puandan $86.4 \pm 8.7$ puana yükselirken $(\mathrm{p}<0.001)$ ortalama GAÖ skoru grup A'da $6.0 \pm 1.0$ 'dan $1.3 \pm 1.2$ 'ye, grup B'de 6.4 \pm 1.0 'dan $1.0 \pm 0.8$ 'e düştü $(\mathrm{p}<0.001)$. Kontrol MRG'lere göre, tekrar yırtık oranı grup A'da \%10.9 $(n=7)$ ve grup B'de $\% 8.8(\mathrm{n}=5)$ idi. Gruplar arasında ne klinik skorlarda ne de tekrar yırtık oranlarında istatistiksel olarak anlamlı farklılık bulunmadı $(\mathrm{p}>0.05)$.

Sonuç: Medial düğümlü tekniğe kıyasla daha az zaman alan ve daha basit olan düğümsüz teknik, ameliyattan en az bir yıl sonra benzer tatmin edici sonuçlar sağlar.

Anahtar sözcükler: Çift sıra, düğümsüz dikiş köprüsü, medial düğümlü dikiş köprüsü, rotator manşet onarımı, transosseöz eşdeğeri onarım.

Received: June 17, 2019 Accepted: August 27, 2019 Published online: October 24, 2019

Correspondence: Barıș Polat, MD. Girne Üniversitesi Dr. Suat Günsel Hastanesi, Ortopedi ve Travmatoloji Anabilim Dalı, Sehit Yahya Bakir Sokak, 99320 Karakum, Girne, KKTC. Tel: +90392-6502630 e-mail: drbpolat@hotmail.com 
Over the last years, significant advancements have been made in the arthroscopic repair techniques of rotator cuff tears. ${ }^{[1]}$ Since single-row repair was shown to be unsuccessful in restoring the footprint contact area, double-row repairs, which use two rows of fixation concomitantly to reestablish the normal rotator cuff footprint and increase the contact area for healing, have gained popularity. ${ }^{[2,3]}$ On the other hand, despite increasing footprint contact area, traditional double-row suture anchor repairs do not have the potential to increase tendon-bone interface pressure..$^{[4]}$ Park et al. ${ }^{[8]}$ described the transosseousequivalent (TOE) technique to make up for the several shortcomings of the traditional double-row repair and studies have shown a lower re-tear rate and better clinical results with the TOE technique compared to the traditional double-row and singlerow techniques. ${ }^{[5-9]}$

Transosseous-equivalent repairs can be performed using several suture configurations, but are generally divided between those in which the medial row is tied and all-knotless repairs (Figure 1a, b, 2a, b). Each technique has its own advantages and shortcomings. Biomechanical studies have shown that tying the medial row improves the yield load, ultimate load, and gap formation. ${ }^{[10,11]}$ However, proponents of knotless repairs claim that there are no differences in the repair strength or clinical outcomes, and they emphasize the improved self-reinforcement of
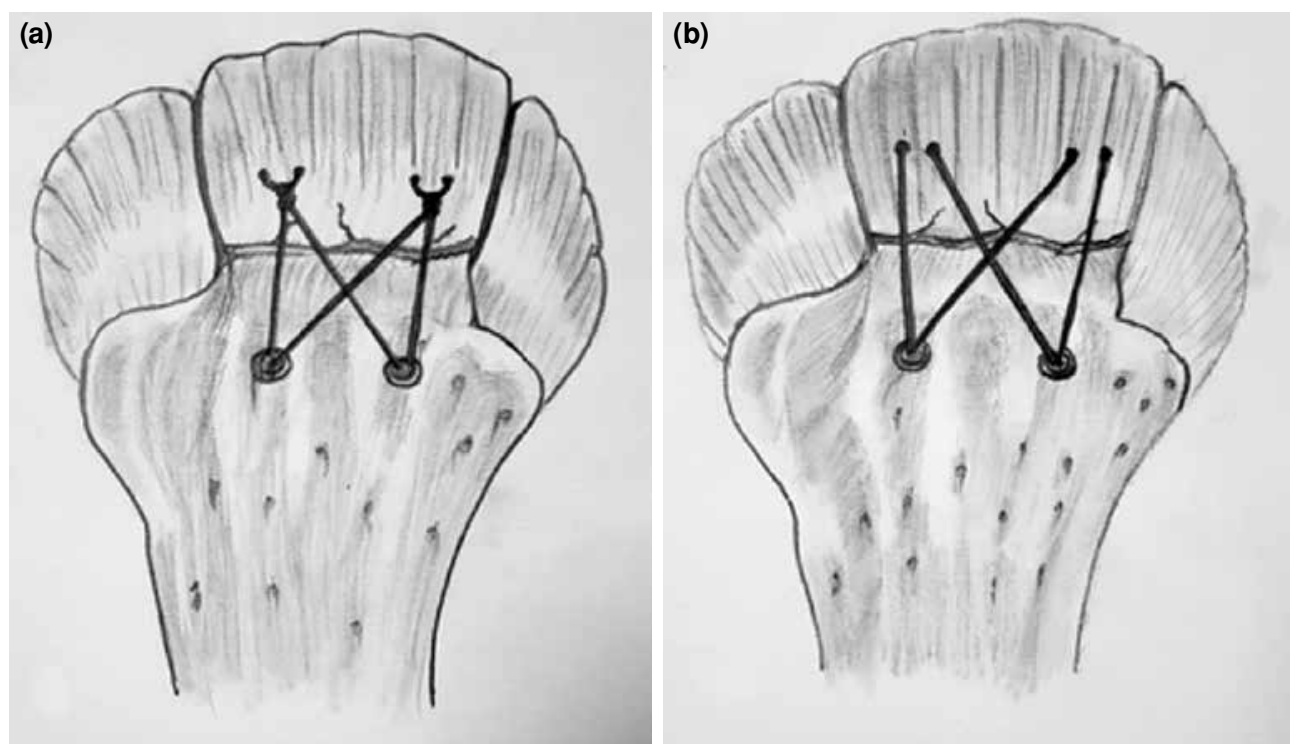

Figure 1. Main double-row repair constructs. (a) Medial knotted transosseous-equivalent repair and (b) knotless transosseous-equivalent repair.
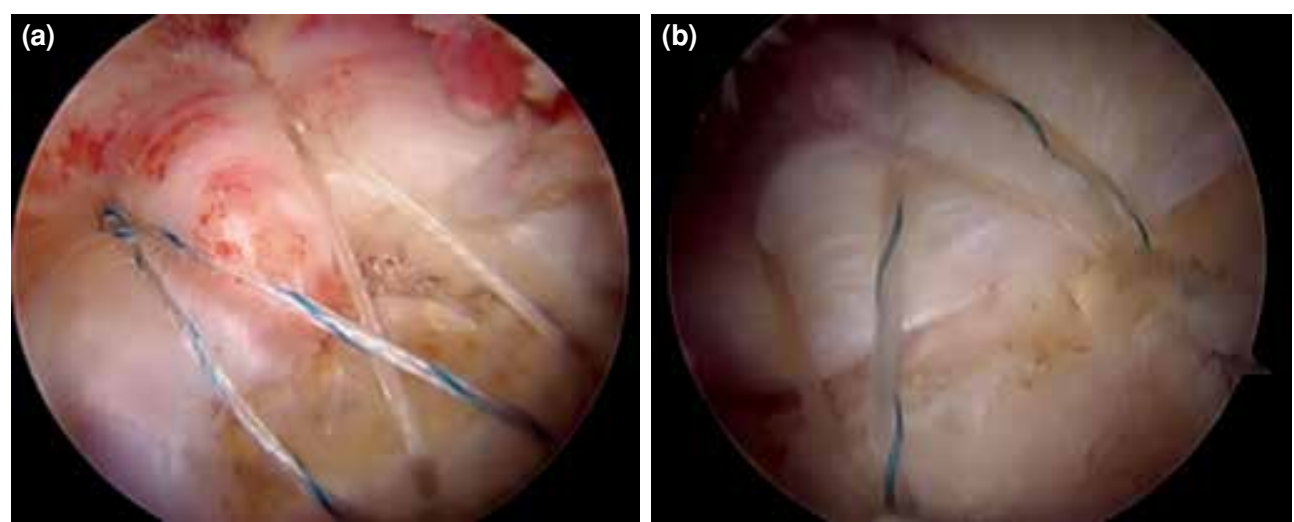

Figure 2. Repair construct with arthroscopic examples. (a) Medial knotted transosseous-equivalent repair and (b) knotless transosseous-equivalent repair. 
knotless suture bridge repairs compared to those with tied medial knots. ${ }^{[12]}$ On the other hand, while studies have mostly compared the biomechanical results of these techniques, the clinical effects have not been widely studied.

In this study, we hypothesized that the knotless technique has as good clinical results as the knot tying techniques, is less time-consuming and a simpler method. Thus, in this study, we aimed to compare the clinical results and repair integrity of the two commonly used TOE arthroscopic rotator cuff repair (RCR) techniques, which are the knotless and the medial knotted suture bridge, for patients with fullthickness medium to large-sized rotator cuff tears.

\section{PATIENTS AND METHODS}

This study was conducted at İstanbul Training and Research Hospital between January 2016 and January 2018. The study included 121 patients (55 males, 66 females; mean age $56.7 \pm 7.3$ years; range, 39 to 72 years) with cuff tears. Cuff tears were diagnosed primarily by physical examination and magnetic resonance imaging (MRI). Symptoms that lasted over six months and failure of conservative treatment were considered as surgical indicators. In order to recruit homogenous groups, only patients with medium- $(1-3 \mathrm{~cm})$ and large-sized tears $(3-5 \mathrm{~cm})$ and non-retracted tears (Patte stage I or II) were enrolled. The tear size was measured preoperatively with MRI. The exclusion criteria included patients who had retracted tears (Patte stage III), small $(<1 \mathrm{~cm})$ or massive rotator cuff tears $(>5 \mathrm{~cm})$, subscapularis tears, acute or traumatic tears, patients who had undergone revision procedures, were older than 75 years, had acromioclavicular arthritis that required distal clavicle resection, had advanced glenohumeral arthritis or had fatty infiltration of the rotator cuff classified as higher than Goutallier stage II. Initially, 186 patients were enrolled; however, in 53 patients, different surgical techniques or additional procedures were required during the surgery since the MRI findings did not match with the intraoperative findings (smaller tears, massive tears, retracted tears, subscapularis repair). In addition, 12 patients were lost to follow-up or refused postoperative MRI evaluation. Therefore, 121 patients were enrolled finally. The decision to perform either a tied construct or a knotless repair was made by the surgeon arbitrarily since there has not been any proof favoring one construct over the other. Patients were operated alternately with one of the two repair techniques (a knotless or conventional knotted suture bridge technique). All patients were operated by the first author. Consequently, 64 shoulders were operated with the conventional medial knotted suture bridge technique (group A) and 57 shoulders were operated with the knotless suture bridge technique (group B). The study protocol was approved by the İstanbul Training and Research Hospital Ethics Committee (ID: 1041). A written informed consent was obtained from each patient. The study was conducted in accordance with the principles of the Declaration of Helsinki.

Patients' age, gender, body mass index (BMI), smoking status, tear size on sagittal MRIs, and tear retraction on coronal MRIs were recorded preoperatively. All patients underwent physical examination the day before surgery. Postoperative evaluations were performed regularly on an outpatient basis (at the $2^{\text {nd }}, 4^{\text {th }}$ and $6^{\text {th }}$ weeks, at the $3^{\text {rd }}, 6^{\text {th }}, 9^{\text {th }}$ and $12^{\text {th }}$ months postoperatively and at the last follow-up). All complications, re-tears and pull-out of the anchors were noted. Shoulder stiffness was considered in case of a passive forward flexion of less than $120^{\circ}$, passive external rotation of less than $30^{\circ}$ with the arm at the side, and passive internal rotation at the back lower than the L3. ${ }^{[13]}$ Data were collected to determine the Constant score. Pre- and postoperative subjective pain scores were measured with the visual analog scale (VAS). The active forward flexion angle was evaluated using a goniometer pre- and postoperatively. The evaluation of the clinical scores was performed by the investigator blinded to the surgical technique.

Preoperative tear sizes and postoperative control images were evaluated by the same radiologist experienced in shoulder imaging and by the first author. The examiners were blinded to the groups. In case of disagreement between the examiners, reevaluation was made until a consensus was reached. Postoperative control imaging was performed at a mean of $19 \pm 4.7$ months. All examinations were performed using a 1.5 Tesla whole body MRI scanner (Signa ${ }^{\circledR}$ HDxt; GE Medical Systems, Milwaukee, WI, USA) with a $33 \mathrm{mT} / \mathrm{m}$ maximum gradient capacity. T2-weighted spin-echo images on the axial, coronal and sagittal planes were obtained. Postoperative cuff integrity was grouped under five categories based on Sugaya et al.'s classification on T2-weighted images. ${ }^{[14]}$

\section{Statistical analysis}

The mean, standard deviation, median lowest, highest, frequency and ratio values were used in the descriptive statistics. Distribution of the variables was measured using the Kolmogorov-Smirnov test. The independent samples t-test and Mann-Whitney U test were used for the analysis of independent quantitative 
data and the Wilcoxon test was used for dependent quantitative data. In the analysis of independent qualitative data, the chi-square test was utilized. Analyses were performed using the IBM SPSS version 22.0 statistical software (IBM Corp., Armonk, NY, USA). Statistical significance was considered to be present at a level of $p<0.05$. Interobserver agreement was assessed using the kappa $(\kappa)$ statistical test. A $\kappa$ value between 0.8 and 1 was considered to indicate perfect agreement.

\section{RESULTS}

No significant differences were detected between groups $\mathrm{A}$ and $\mathrm{B}$ in terms of age, gender, BMI, operated side and dominant side distribution and smoking rate $(p>0.05)$. Similarly, anteroposterior extension of the tear on sagittal MRIs and tear size distribution were not significantly different in the two groups $(p>0.05)$. Intraoperative biceps tenotomy was performed on $35.9 \% \quad(n=23)$ of the patients in group $A$ and $35.1 \%(n=20)$ of the patients in group B. Also, biceps tenodesis was performed on $9.4 \%$ $(n=6)$ of the patients in group A and $7 \%(n=4)$ of the patients in group B (Table I).
Patients' functionality was assessed after a mean of $19 \pm 4.7$ months in both groups. Overall, the mean Constant scores and forward flexion angles were significantly improved and the VAS scores were significantly decreased when compared to the baseline values $(p<0.001)$. There was no statistically significant difference between the groups in terms of postoperative Constant score $(\mathrm{p}=0.360)$, VAS score $(\mathrm{p}=0.279)$ and active forward flexion angle $(\mathrm{p}=0.830)$ (Table II).

A follow-up MRI was also available for all shoulders at a mean of $19 \pm 4.7$ months postoperatively. The re-tear rate was $10.9 \%(n=7)$ in shoulders with knotted suture bridge repair and $8.8 \%(n=5)$ in shoulders with knotless suture bridge repair. Two re-tear patterns were observed: the lateral and medial integrity failure. Three of the re-tears in group A were medial failures at the musculotendinous junction (type 2 tears) and four were lateral failures. In group B, two of the re-tears were medial and three were lateral (Figure 3).

The preoperative Constant, VAS and forward flexion values did not show significant difference

TABLE I

Distribution of demographic characteristics in both groups

\begin{tabular}{|c|c|c|c|c|c|c|c|c|c|}
\hline & & & roup $A$ & & & & roup B & & \\
\hline & $\mathrm{n}$ & $\%$ & Mean $\pm S D$ & Median & $n$ & $\%$ & Mean $\pm S D$ & Median & $p$ \\
\hline Age (year) & & & $56.7 \pm 7.7$ & 58.0 & & & $56.6 \pm 7.0$ & 57.0 & 0.908 \\
\hline Gender & & & & & & & & & 0.287 \\
\hline Female & 32 & 50.0 & & & 34 & 59.6 & & & \\
\hline Male & 32 & 50.0 & & & 23 & 40.4 & & & \\
\hline Body mass index & & & $31.2 \pm 3.9$ & 31.0 & & & $31.5 \pm 4.3$ & 31.0 & 0.745 \\
\hline Side & & & & & & & & & 0.143 \\
\hline Right & 41 & 64.1 & & & 29 & 50.9 & & & \\
\hline Left & 23 & 35.9 & & & 28 & 49.1 & & & \\
\hline Dominant side & & & & & & & & & 0.939 \\
\hline Right & 52 & 81.3 & & & 46 & 80.7 & & & \\
\hline Left & 12 & 18.8 & & & 11 & 19.3 & & & \\
\hline Smoke & & & & & & & & & 0.255 \\
\hline- & 41 & 64.1 & & & 42 & 73.7 & & & \\
\hline+ & 23 & 35.9 & & & 15 & 26.3 & & & \\
\hline Re-tear & & & & & & & & & 0.691 \\
\hline - & 57 & 89.1 & & & 52 & 91.2 & & & \\
\hline+ & 7 & 10.9 & & & 5 & 8.8 & & & \\
\hline Biceps tenotomy & & & & & & & & & 0.922 \\
\hline- & 41 & 64.1 & & & 37 & 64.9 & & & \\
\hline+ & 23 & 35.9 & & & 20 & 35.1 & & & \\
\hline Anteroposterior extension of tear (mm) & & & $23.8 \pm 11.0$ & 20.5 & & & $24.1 \pm 11.6$ & 24.0 & 0.944 \\
\hline Anteroposterior extension of tear & & & & & & & & & 0.387 \\
\hline Medium & 46 & 71.9 & & & 40 & 70.2 & & & \\
\hline Large & 18 & 28.1 & & & 17 & 29.8 & & & \\
\hline Follow up period (months) & & & $19.3 \pm 4.7$ & 18.0 & & & $18.7 \pm 4.6$ & 18.0 & 0.485 \\
\hline
\end{tabular}

SD: Standard deviation. 
TABLE II

Distribution of functional results in groups

\begin{tabular}{|c|c|c|c|c|c|}
\hline & \multicolumn{2}{|c|}{ Group A } & \multicolumn{2}{|c|}{ Group B } & \multirow[b]{2}{*}{$p$} \\
\hline & Mean \pm SD & Median & Mean $\pm S D$ & Median & \\
\hline \multicolumn{6}{|l|}{ Constant score } \\
\hline Preoperative & $32.3 \pm 8.5$ & 32.0 & $31.3 \pm 9.3$ & 31.0 & 0.333 \\
\hline Postoperative & $84.0 \pm 11.6$ & 86.0 & $86.4 \pm 8.7$ & 86.0 & 0.360 \\
\hline Difference $p$ & $<0.001$ & & $<0.001$ & & \\
\hline \multicolumn{6}{|c|}{ Visual analog scale } \\
\hline Preoperative & $6.0 \pm 1.0$ & 6.0 & $6.4 \pm 1.0$ & 6.0 & 0.078 \\
\hline Postoperative & $1.3 \pm 1.2$ & 1.0 & $1.0 \pm 0.8$ & 1.0 & 0.279 \\
\hline Difference $p$ & $<0.001$ & & $<0.001$ & & \\
\hline \multicolumn{6}{|l|}{ Forward flexion } \\
\hline Preoperative & $105.3 \pm 26.1$ & 110.0 & $104.6 \pm 22.6$ & 110.0 & 0.898 \\
\hline Postoperative & $153.3 \pm 25.5$ & 160.0 & $155.6 \pm 20.5$ & 160.0 & 0.830 \\
\hline Difference $p$ & $<0.001$ & & $<0.001$ & & \\
\hline
\end{tabular}

SD: Standard deviation.

$(p>0.05)$ between the patients with re-tears and no re-tears. In the re-tear group, the postoperative Constant, VAS and forward flexion values were significantly lower than those without re-tears $(\mathrm{p}<0.05)$ (Table III).

There were no major intra- or postoperative complications, such as infection and vessel or nerve injury. Postoperative stiffness in group A was observed in five patients in the third month and in two patients in the sixth month, whereas the same was observed in five patients in the third month and in three patients in the sixth month in group B. All of the patients with stiffness were satisfied with their final range of motion (ROM). No surgical release was performed on these patients. Interobserver agreement (к) was 0.93 for the preoperative tear size and 0.84 for the postoperative evaluation of structural integrity.

\section{DISCUSSION}

The most remarkable outcome of the current study is that TOE RCR using either a medial knotted or a knotless construct showed significantly improved functional scores at a minimum of 12 months postoperatively. Our results in terms of pain relief, ROM and clinical scores are in accordance with those of previous studies reporting RCR by
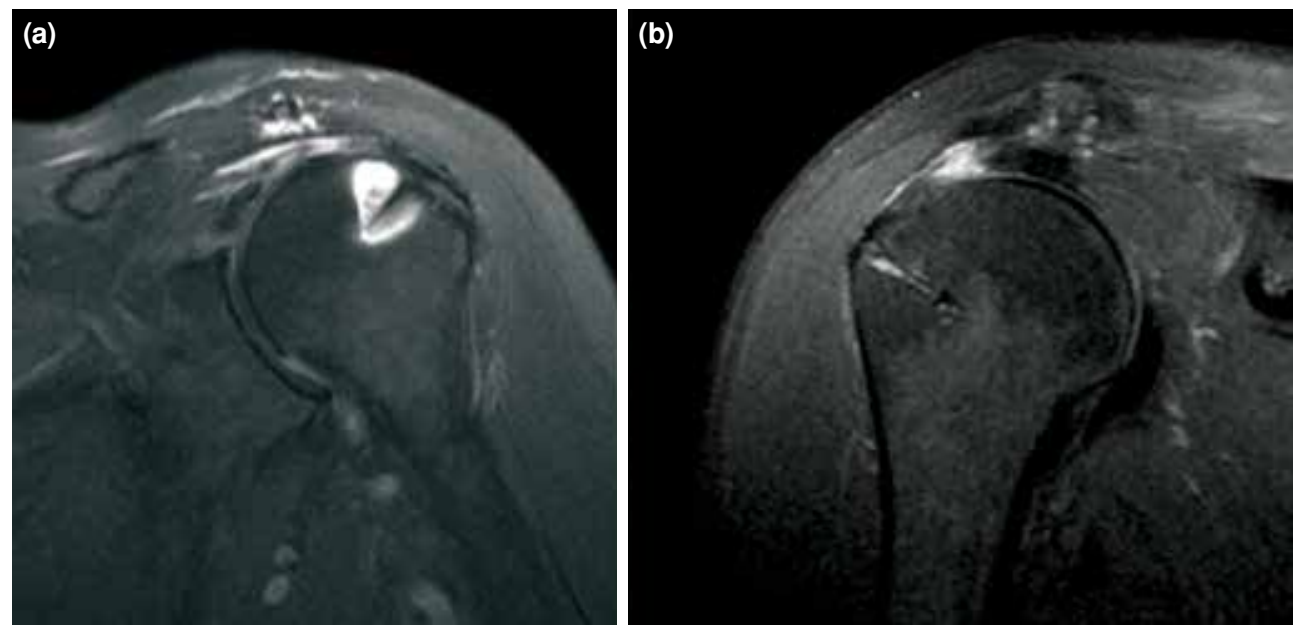

Figure 3. (a) Postoperative coronal magnetic resonance imaging section of a patient who underwent medial knotless transosseous-equivalent rotator cuff repair taken on the $17^{\text {th }}$ month showing re-tear. (b) Postoperative coronal magnetic resonance imaging section of a patient who underwent medial knotted transosseous-equivalent rotator cuff repair taken on the $14^{\text {th }}$ month showing re-tear. 
TABLE III

Comparison of clinical results of groups with and without re-tear

\begin{tabular}{|c|c|c|c|c|c|}
\hline & \multicolumn{2}{|c|}{ Re-tear (-) } & \multicolumn{2}{|c|}{ Re-tear (+) } & \multirow[b]{2}{*}{$p$} \\
\hline & Mean $\pm S D$ & Median & Mean $\pm S D$ & Median & \\
\hline \multicolumn{6}{|l|}{ Constant score } \\
\hline Preoperative & $32.3 \pm 9.0$ & 32.0 & $27.3 \pm 6.0$ & 27.5 & 0.060 \\
\hline Postoperative & $86.7 \pm 8.8$ & 87.0 & $71.3 \pm 13.3$ & 77.0 & $<0.001$ \\
\hline Difference $p$ & $<0.001$ & & 0.002 & & \\
\hline \multicolumn{6}{|c|}{ Visual analog scale } \\
\hline Preoperative & $6.2 \pm 1.0$ & 6.0 & $5.9 \pm 0.9$ & 6.0 & 0.301 \\
\hline Postoperative & $1.1 \pm 1.0$ & 1.0 & $1.7 \pm 1.0$ & 1.5 & 0.023 \\
\hline Difference $p$ & $<0.001$ & & $<0.001$ & & \\
\hline \multicolumn{6}{|l|}{ Forward flexion } \\
\hline Preoperative & $105.6 \pm 25.0$ & 110.0 & $100.0 \pm 18.1$ & 105.0 & 0.355 \\
\hline Postoperative & $159.6 \pm 16.4$ & 160.0 & $106.7 \pm 22.3$ & 110.0 & $<0.001$ \\
\hline Difference $p$ & $<0.001$ & & 0.570 & & \\
\hline
\end{tabular}

SD: Standard deviation.

suture bridging. ${ }^{[15,16]}$ However, we did not observe any statistical differences between the groups in terms of clinical outcomes and re-tear rates.

Biomechanical factors such as ultimate load, stiffness, gap formation, and contact area are the main concerns regarding knotless constructs. In a biomechanical study, Busfield et al. ${ }^{[17]}$ compared the biomechanical properties of knotless and medial knotted groups in six pairs of cadaveric shoulders and found that the yield load, ultimate load and the energy absorbed decreased by $22 \%, 28 \%$, and $41 \%$, respectively, in the knotless group. In addition, gap formation increased in the knotless group. In a similar study, Leek et al. ${ }^{[10]}$ found that medially knotted constructs had significantly higher stiffness than the trans-tendon constructs at both the initial and final cycles, and showed a significantly lower total displacement during cyclic loading. On the other hand, a potential biomechanical advantage of knotless constructs is "self-reinforcement". Self-reinforcement in RCR is a mechanism where increasing the tensile load can generate increased resistance to structural failure ${ }^{[18]}$ It is proposed that the increased tensile forces create an increased compressive force at the tendon footprint and therefore, the compressive forces provide frictional resistance to gap formation. ${ }^{[18]}$ Recently, a biomechanical study compared the footprint contact pressure generated under progressive tensile loads between knotless and medial knotted RCR techniques and found that self-reinforcement was greater in the knotless method. ${ }^{[12]}$ In conclusion, although both techniques seem to have different biomechanical advantages, it is not possible to say which one has a superior clinical effect on the healing of the rotator cuff since our results were also similar.

Healing is a complex process and is not only associated with biomechanics. Suture bridging techniques are mostly questioned in regard to the tendon's blood supply. In a recent study, the blood flow at the repair site in 18 patients was measured by Doppler during standard medial knotted suture bridge fixation and the results showed a significant decline $(44.6 \%)$ in the blood flow after placement of the second row of implants. ${ }^{[19]}$ It is claimed that this decline in blood flow can compromise tendon healing. Furthermore, in the medial knotted technique, there may be a possibility of strangulation, which may worsen the blood flow and cause a relatively quick necrosis of the rotator cuff tendon at the medial row. ${ }^{[20]}$

Medial cuff re-tears were first described by Trantalis et al., ${ }^{[21]}$ and subsequently, it was shown that they were associated with double-row and suture bridge RCR techniques. ${ }^{[22]}$ This unusual pattern of tendon failure is observed in the musculotendinous junction of the rotator cuff, and among many causes, strangulations in the medial knotted technique have been blamed. In an attempt to reduce the possibility of strangulation, different stitching techniques, such as the modified lasso-loop or the modified Mason-Allen, have been proposed for the medial row. ${ }^{[20,23]}$ Rhee et al. ${ }^{[20]}$ found that the re-tear rate was significantly lower in the knotless group, in which they performed the modified Mason-Allen stitching in the medial row (5.9\%), compared to the conventional medial knotted group (18.6\%). In addition, the authors did not observe 
any medial cuff re-tear in the knotless group, whereas $72.7 \%$ of the re-tears occurred at the musculotendinous junction in the conventional medial knotted group. In our study, we have not seen any statistically significant differences in terms of either re-tear rates or re-tear types between the knotless and the medial knotted groups. Medial re-tears were present in both groups, being slightly lower in knotless repairs, but with an insignificant difference. Since we encountered such atypical re-tears in both groups, we believe there are different reasons for the medial tears other than strangulation of the medial knotted construct. The number of patients with medial cuff re-tears $(n=5)$ in our study was too small to allow for definitive conclusions. Boyer et al. ${ }^{[15]}$ compared the results of 38 shoulders which were repaired by the knotted suture bridging technique to 35 shoulders repaired with knotless bridging with suture tape material. In terms of structural outcomes, the authors found a lower re-tear rate with the knotless tape-bridging construct, which was insignificant. However, in their study, the tear type was different. The authors observed two medial cuff re-tears and seven lateral cuff re-tears in the medial knotted group, whereas there were six lateral tears but no medial tears in the knotless tapebridging construct group. On the other hand, the functional outcomes were similar in both groups.

The limitations of our study were the limited number of patients, the retrospective design, and the lack of randomization. In addition, we could followup on the patients only for a short period of time.

In conclusion, the medial knotted TOE RCR technique does not have any superior clinical outcomes or repair integrity compared to the knotless technique. Less time-consuming and simpler knotless techniques provide similar satisfactory outcomes after a minimum period of one year postoperatively.

\section{Declaration of conflicting interests}

The authors declared no conflicts of interest with respect to the authorship and/or publication of this article.

\section{Funding}

The authors received no financial support for the research and/or authorship of this article.

\section{REFERENCES}

1. Acan AE, Hapa O, Horoz L, Kara A, Havıtçığlu H. Effects of a lateral row anchor position on the suture holding strength of a double-row knotless fixation in rotator cuff repair. Eklem Hastalik Cerrahisi 2018;29:46-51.

2. Lo IK, Burkhart SS. Double-row arthroscopic rotator cuff repair: re-establishing the footprint of the rotator cuff. Arthroscopy 2003;19:1035-42.
3. Tuoheti $Y$, Itoi E, Yamamoto N, Seki N, Abe H, Minagawa H, et al. Contact area, contact pressure, and pressure patterns of the tendon-bone interface after rotator cuff repair. Am J Sports Med 2005;33:1869-74.

4. Dines JS, Bedi A, ElAttrache NS, Dines DM. Single-row versus double-row rotator cuff repair: techniques and outcomes. J Am Acad Orthop Surg 2010;18:83-93.

5. Carbonel I, Martínez AA, Aldea E, Ripalda J, Herrera A. Outcome and structural integrity of rotator cuff after arthroscopic treatment of large and massive tears with double row technique: a 2-year followup. Adv Orthop 2013;2013:914148.

6. Frank JB, ElAttrache NS, Dines JS, Blackburn A, Crues J, Tibone JE. Repair site integrity after arthroscopic transosseous-equivalent suture-bridge rotator cuff repair. Am J Sports Med 2008;36:1496-503.

7. Imam MA, Abdelkafy A2. Outcomes following arthroscopic transosseous equivalent suture bridge double row rotator cuff repair: a prospective study and short-term results. SICOT J 2016;2:7.

8. Park MC, ElAttrache NS, Tibone JE, Ahmad CS, Jun BJ, Lee TQ. Part I: Footprint contact characteristics for a transosseous-equivalent rotator cuff repair technique compared with a double-row repair technique. J Shoulder Elbow Surg 2007;16:461-8.

9. Park MC, Tibone JE, ElAttrache NS, Ahmad CS, Jun BJ, Lee TQ. Part II: Biomechanical assessment for a footprintrestoring transosseous-equivalent rotator cuff repair technique compared with a double-row repair technique. J Shoulder Elbow Surg 2007;16:469-76.

10. Leek BT, Robertson C, Mahar A, Pedowitz RA. Comparison of mechanical stability in double-row rotator cuff repairs between a knotless transtendon construct versus the addition of medial knots. Arthroscopy 2010;26:S127-33.

11. Mall NA, Lee AS, Chahal J, Van Thiel GS, Romeo AA, Verma NN, et al. Transosseous-equivalent rotator cuff repair: a systematic review on the biomechanical importance of tying the medial row. Arthroscopy 2013;29:377-86.

12. Smith GCS, Bouwmeester TM, Lam PH. Knotless double-row SutureBridge rotator cuff repairs have improved self-reinforcement compared with doublerow SutureBridge repairs with tied medial knots: a biomechanical study using an ovine model. J Shoulder Elbow Surg 2017;26:2206-12

13. Oh JH, Kim SH, Lee HK, Jo KH, Bin SW, Gong HS. Moderate preoperative shoulder stiffness does not alter the clinical outcome of rotator cuff repair with arthroscopic release and manipulation. Arthroscopy 2008;24:983-91.

14. Sugaya H, Maeda K, Matsuki K, Moriishi J. Functional and structural outcome after arthroscopic full-thickness rotator cuff repair: single-row versus dual-row fixation. Arthroscopy 2005;21:1307-16.

15. Boyer P, Bouthors C, Delcourt T, Stewart O, Hamida F, Mylle G, Massin P. Arthroscopic double-row cuff repair with suture-bridging: a structural and functional comparison of two techniques. Knee Surg Sports Traumatol Arthrosc 2015;23:478-86.

16. El-Azab H, Buchmann S, Beitzel K, Waldt S, Imhoff AB. Clinical and structural evaluation of arthroscopic doublerow suture-bridge rotator cuff repair: early results of a novel technique. Knee Surg Sports Traumatol Arthrosc 2010;18:1730-7. 
17. Busfield BT, Glousman RE, McGarry MH, Tibone JE, Lee TQ. A biomechanical comparison of 2 technical variations of double-row rotator cuff fixation: the importance of medial row knots. Am J Sports Med 2008;36:901-6.

18. Park MC, McGarry MH, Gunzenhauser RC, Benefiel MK, Park CJ, Lee TQ. Does transosseous-equivalent rotator cuff repair biomechanically provide a "self-reinforcement" effect compared with single-row repair? J Shoulder Elbow Surg 2014;23:1813-21.

19. Christoforetti JJ, Krupp RJ, Singleton SB, Kissenberth MJ, Cook C, Hawkins RJ. Arthroscopic suture bridge transosseus equivalent fixation of rotator cuff tendon preserves intratendinous blood flow at the time of initial fixation. J Shoulder Elbow Surg 2012;21:523-30.
20. Rhee YG, Cho NS, Parke CS. Arthroscopic rotator cuff repair using modified Mason-Allen medial row stitch: knotless versus knot-tying suture bridge technique. Am J Sports Med 2012;40:2440-7.

21. Trantalis JN, Boorman RS, Pletsch K, Lo IK. Medial rotator cuff failure after arthroscopic double-row rotator cuff repair. Arthroscopy 2008;24:727-31.

22. Cho NS, Yi JW, Lee BG, Rhee YG. Retear patterns after arthroscopic rotator cuff repair: single-row versus suture bridge technique. Am J Sports Med 2010;38:664-71.

23. Toussaint B, Schnaser E, Lafosse L, Bahurel J, Gobezie R. A new approach to improving the tissue grip of the medialrow repair in the suture-bridge technique: the "modified lasso-loop stitch". Arthroscopy 2009;25:691-5. 